\title{
PENGARUH PERTUMBUHAN EARNING PER SHARE, DIVIDEN PER \\ SHARE, RETURN ON INVESTMENT DAN RETURN ON EQUITY \\ TERHADAP RETURN SAHAM PADA PERUSAHAAN YANG \\ TERDAFTAR DI LQ 45
}

\author{
Amir Hidayatulloh \\ Beni Suhendra Winarso
}

\begin{abstract}
The objective of this research is to find out the effect of the growth of earning per share, deviden per share, return on investment and return on equity of stock return on registered companies in the $L Q 45$. The populations of this research are companies in Indonesian Stock Exchange. The sampling technique in this research uses by purposive sampling with the available data in 2005 -2006, registered in the LQ-45 period 2006 - 2010 respectively, announced a profit and distributing dividends in a row, so that the sample used amounted to 15 companies. The statistical method used is multiple regresion to test a classical assumtion first. $T$ statistical test show that the growth of Earning Per Share effect on stock return $H+3$, growth Dividend Per Share effect on stock return in the $\mathrm{H}-5$ and $H+4$, growth of Return On Investment effect on stock return in return $H+1$, whereas Return On Equity effect on stock return $\mathrm{H}+3$
\end{abstract}

Keywords: Earning Per Share, Dividen Per Share, Return On Investment, Return On Equity, Stock Return

\section{PENDAHULUAN}

Pasar Modal adalah tempat terjadinya transaksi aset keuangan jangka panjang atau long-term financial asset. Jenis surat berharga yang diperjual belikan di pasar modal memiliki jatuh tempo lebih dari 1 tahun dan bentuk secara umum adalah obligasi, saham preferen dan saham biasa (Sartono, 1997: 11). Menurut undangundang no. 8 tahun 1995 menjelaskan bahwa pasar modal berkaitan dengan yang namanya bursa efek. Definisi dari bursa efek itu sendiri adalah pihak yang menyelenggarakan dan menyediakan sistem dan atau sarana untuk mempertemukan penawaran jual dan beli efek pihak lain dengan tujuan memperdagangkan efek diantara mereka, yang memiliki fungsi menciptakan pasar secara terus-menerus bagi efek yang telah ditawarkan kepada masyarakat, menciptakan harga wajar bagi efek yang bersangkutan melalui mekanisme pasar, membantu pemenuhan dana 
dunia usaha melalui penghimpunan dana masyarakat dan memperluas proses perluasan partisipasi masyarakat dalam pemilikan saham-saham perusahaan

Beberapa indikator yang dapat menunjukkan pertumbuhan kinerja suatu perusahaan dimana dapat menarik para investor untuk menanamkan modalnya. Indikator tersebut antara lain earning per share (EPS), deviden per share (DPS), return on investment (ROI) dan return on equity (ROE). Susilo (2009: 27) mengemukakan bahwa investor menginvestasikan dananya dalam bentuk saham maka akan memperoleh keuntungan berupa deviden dan capital gain. Dividen diberikan setelah mendapat persetujuan dari pemegang saham dalam Rapat Umum Pemegang Saham (RUPS). Sedangkan untuk capital gain diperoleh dari selisih antara harga beli saham dengan harga jualnya. Menurut Garisalam dan Widodo (2003) dalam Natsir (2007) menjelaskan bahwa perubahan harga saham dipengaruhi oleh berbagai faktor, antara lain: prospek laba, arus kas, pembagian deviden, laba per saham, stock split, growth yang akan diperoleh dimasa yang akan datang, serta keadaan ekonomi makro dari suatu negara atau dunia.

Earning per share (EPS) merupakan perbandingan antara jumlah earning dengan jumlah saham beredar. EPS digunakan oleh investor karena dapat menggambarkan prospek earning suatu perusahaan di masa yang akan datang dimana menunjukkan informasi mengenai laba bersih perusahaan yang akan dibagikan kepada pemegang saham perusahaan. Semakin besar nilai EPS akan dapat menarik investor untuk melakukan investasi di perusahaan tersebut. EPS juga digunakan oleh pimpinan perusahaan untuk menentukan dividen yang dibagikan kepada pemegang saham atau sering disebut dengan Dividen Per Share (DPS). Dividen akan dibagikan kepada pemegang saham apabila perusahaan mendapatkan laba. Setiap investor akan merespon perusahaan yang memberikan deviden, yang ditunjukkan dengan tingginya harga saham perusahaan tersebut dan akhirnya akan mempengaruhi return saham, Husnan (2001) dalam Natsir (2007)

Return saham merupakan hasil yang diperoleh dari investasi. Return dapat berupa return realisasian yang sudah terjadi atau return ekspektasian yang belum terjadi tetapi yang diharapkan akan terjadi di masa yang akan datang. Return realisasian merupakan return yang terjadi, return realisasian penting karena 
digunakan sebagai salah satu pengukur kinerja dari perusahaan dan sebagai penentu return ekspektasian dan risiko di masa yang akan datang (Hartono, 2009: 557)

Husnan (1998: 557) mengemukakan bahwa investor akan lebih berkepentingan dengan prospek probabilitas perusahaan di masa yang akan datang, sehingga calon pemodal (pembeli saham) perlu melakukan analisis rasio probabilitas. Rasio probabilitas adalah rasio yang digunakan untuk mengukur efisiensi penggunaan aktiva perusahaan, mungkin juga rasio probabilitas dikaitkan dengan keberhasilan penjualan yang berhasil diciptakan, maka rasio yang digunakan dalam penelitian ini adalah Return On Equity (ROE) dan Return On Investmet (ROI). ROE digunakan untuk mengukur tingkat investasi yang menggunakan dana dari pemilik perusahaan saja. Sedangkan ROI digunakan untuk mengukur tingkat investasi yang menggunakan dana dari seluruh kekayaan yang dimiliki perusahaan. Dari penjelasan sebelumnya maka penulis tertarik untuk meneliti mengenai pengaruh pertumbuhan earning per share, deviden per share, return on investment, dan return on equity terhadap return saham pada perusahaan yang terdaftar di LQ 45"

\section{TINJAUAN PUSTAKA DAN PENGEMBANGAN HIPOTESIS}

\section{Return Saham}

Hartono (2009: 557) mengemukakan bahwa return saham merupakan hasil yang diperoleh dari investasi. Return dapat berupa return realisasian yang sudah terjadi atau return ekspektasian yang belum terjadi tetapi yang diharapkan akan terjadi di masa yang akan datang. Return realisasian merupakan return yang terjadi, return realisasian penting karena digunakan sebagai salah satu pengukur kinerja dari perusahaan dan sebagai penentu return ekspektasian dan risiko di masa yang akan datang. Pengukuran return realisasian menggunakan:

1. Return total merupakan keseluruhan dari suatu investasi dalam suatu periode tertentu, return total terdiri dari capital gain (loss) dan yield.

2. Return relatif dapat bernilai negatif maupun positif, return relatif dapat dilakukan yaitu dengan menambah nilai satu terhadap return total. 
3. Kumulatif return, untuk mengetahui total kemakmuran dapat menggunakan indeks kemakmuran kumulatif (IKK), IKK mengukur akumulasi semua return mulai dari kemakmuran awal yang dimiliki.

4. Return yang disesuaikan, return ini mempertimbangkan tingkat daya beli dan disesuaikan dengan tingkat inflasi yang ada

\section{Earning per Share}

Pendapatan per saham (Earning per Share) adalah jumlah pendapatan yang diperoleh dalam satu periode untuk tiap saham yang beredar. Informasi mengenai pendapatan per lembar saham dapat digunakan oleh pimpinan perusahaan untuk menentukan dividen yang akan dibagikan. Informasi ini juga berguna bagi investor untuk mengetahui perkembangan perusahaan (Baridwan, 1999: 444)

Perusahaan yang mengalami pertumbuhan EPS diisyaratkan mempunyai kinerja yang baik oleh investor, karena pembayaran dividen oleh perusahaan sangat tergantung oleh pertumbuhan laba sehingga perusahaan yang mengalami pertumbuhan laba akan segera direspon oleh investor. Respon ini akan dilihat dari perubahan harga saham perusahaan yang pada akhirnya akan mempengaruhi return saham. Hal ini di dukung oleh penelitian Fitri (2006), Kurnia (2008) dan Santoso (2009).

$\mathrm{H}_{1}$ : Pertumbuhan EPS berpengaruh terhadap return saham perusahaan yang terdaftar di LQ-45 periode 2006 - 2010.

\section{Deviden per Share (DPS)}

Deviden adalah bagian dari laba bersih yang dibagikan kepada para pemegang saham (pemilik modal sendiri). Laba bersih sering disebut sebagai laba yang tersedia bagi pemegang saham (earning available to common stockholder). Selain dibagi kepada pemegang saham dalam bentuk dividen, laba bersih juga ditahan di dalam perusahaan untuk membiayai operasi selanjutnya dan disebut dengan laba ditahan (Napaj, 1999: 121).

Yuanita (2010) mengemukakan bahwa kebijakan pembagian deviden tergantung pada Rapat Umum Pemegang Saham (RUPS). Deviden yang dibagikan perusahaan bisa tetap (tidak mengalami pertumbuhan) dan bisa mengalami 
perubahan (kenaikan atau penurunan) dari deviden yang dibagikan sebelumnya. Salah satu informasi yang cukup penting bagi investor yaitu tentang naik turunnya deviden tunai yang dibagikan perusahaan. Pengumuman deviden mempunyai pengaruh terhadap reaksi pasar yang ditunjukkan dengan perubahan harga saham, return dan volume perdagangan.

Investor sebagai pemegang saham akan merespon perusahaan yang mengalami pertumbuhan deviden. Reaksi ini dapat dilihat dari perubahan harga saham yang akhirnya akan mempengaruhi return saham. Hal ini sesuai dengan relevant theory yang menjelaskan bahwa deviden relevan untuk kondisi tidak pasti atau dengan kata lain investor dapat dipengaruhi oleh kebijakan deviden. Beberapa penelitian terkait dengan indikator ini adalah Widiyastuti (2005) dan Kurnia (2008).

$\mathrm{H}_{2}$ : Pertumbuhan DPS berpengaruh terhadap return saham perusahaan yang terdaftar di LQ-45 periode 2006 - 2010.

\section{Return on Investment (ROI)}

ROI mengukur tingkat kembalian investasi yang telah dilakukan oleh perusahaan, baik dengan menggunakan total aktiva yang dimiliki oleh perusahaan maupun dengan menggunakan dana yang berasal dari pemilik (Prastowo dan Rifka, 2008: 90). ROI menunjukkan kemampuan perusahaan memperoleh laba yang tersedia bagi pemegang saham perusahaan. Rasio ini juga dipengaruhi oleh besar kecilnya hutang perusahaan, apabila proporsi hutang makin besar maka ROI juga akan semakin besar (Sartono, 1997: 65).

Perusahaan yang mengalami pertumbuhan ROI mempengaruhi frekuensi investor. Respon investor dapat dilihat dengan perubahan harga saham yang akhirnya akan mempengaruhi return saham. Penelitian terkait hal tersebut adalah Mulyati (2009).

$\mathrm{H}_{3}$ : Pertumbuhan ROI berpengaruh terhadap return saham perusahaan yang terdaftar di LQ-45 periode 2006 - 2010.

\section{Return on Equity (ROE)}

Salah satu cara untuk mengukur pencapaian kinerja perusahaan untuk memperoleh laba bagi pemegang saham dengan menggunakan return on common 
stockholders equity (ROE) (Prastowo dan Rifka, 2008: 82). ROE atau sering disebut rentabilitas modal sendiri dimaksudkan untuk mengukur seberapa banyak keuntungan yang menjadi hak pemilik modal sendiri (Martono dan Agus Harjito, 2008: 58).

Perusahaan yang mengalami pertumbuhan ROE akan lebih diminati oleh investor. Respon investor ditunjukkan dengan perubahan harga saham yang mempengaruhi return saham. Penelitian yang berkaitan dengan variabel ini adalah oleh Santoso (2008).

$\mathrm{H}_{4}$ : Pertumbuhan $\mathrm{ROE}$ berpengaruh terhadap return saham perusahaan yang terdaftar di LQ-45 periode 2006 - 2010.

\section{Kajian Penelitian Terdahulu}

Widiyastuti (2005) melakukan penelitian tentang pengaruh dividen per share (DPS), return on equity (ROE), dan return on investment (ROI) terhadap harga saham perusahaan telekomunikasi yang terdaftar di BEJ periode 1999-2003. Hasil dari penelitian tersebut adalah bahwa DPS, ROI, dan ROE secara bersama-sama tidak berpengaruh terhadap harga saham, sedangkan secara parsial hanya DPS yang berpengaruh terhadap harga saham. Fitria (2006) meneliti tentang EPS dan DPS terhadap harga saham pada perusahaan manufaktur yang terdaftar di BEJ. Penelitian ini menggunakan sampel perusahaan manufaktur yang terdaftar di Bursa Efek Jakarta yang konsisten memperoleh laba dan membagikan deviden kepada pemegang saham periode 2001-2003. Penelitian ini menyimpulkan bahwa EPS berpengaruh terhadap harga saham sedangkan DPS tidak berpengaruh terhadap harga saham.

Artiani (2008) melakukan penelitian mengenai pengaruh rasio keuangan terhadap pertumbuhan laba pada perusahaan manufaktur dengan skala yang besar dan yang kecil. Penelitian ini menggunakan sampel 25 perusahaan manufaktur berskala besar dan 26 perusahaan manufaktur berskala kecil yang terdaftar di Bursa Efek Jakarta periode 2002-2006. Rasio keuangan yang digunakan adalah current ratio, DER, NPM, total asset turnover, dan ROI. Hasil dari penelitian ini adalah menunjukkan bahwa pada perusahaan manufaktur berskala besar, rasio keuangan tidak berpengaruh pada pertumbuhan laba sedangkan untuk perusahaan manufaktur 
berskala kecil menunjukkan rasio keuangan berpengaruh pada pertumbuhan laba menurut pengujian uji f. Sedangkan berdasarkan hasil uji t menunjukkan bahwa rasio keuangan tidak berpengaruh terhadap pertumbuhan laba perusahaan skala besar maupun skala kecil.

Penelitian yang dilakukan oleh Kurnia (2008) menggunakan indikator DPS, ROI dan EPS terhadap harga saham pada perusahaan manufaktur yang hasilnya menunjukkan bahwa secara serentak DPS, ROI dan EPS berpengaruh terhadap harga saham sedangkan secara parsial hanya DPS dan EPS yang berpengaruh terhadap harga saham. Penelitian ini menggunakan 26 sampel perusahaan manufaktur yang telah terdaftar di BEJ.

Muslimah (2008) dalam penelitiannya menjelaskan bahwa EPS, DER, ROE, dan ROI secara bersama-sama tidak berpengaruh terhadap harga saham PT. Aneka Tambang tbk. Sedangkan penelitian yang dilakukan oleh Kendarto (2009) menunjukkan bahwa EPS, DER, dan ROE baik secara bersama-sama maupun individu tidak berpengaruh terhadap return saham pada perusahaan retail yang terdaftar di BEJ pada periode 2004-2006.

Penelitian yang dilakukan oleh Mulyati (2009) menggunakan indikator ROI dan EVA terhadap return saham perusahaan manufaktur yang terdaftar di BEJ periode 2005-2007. Penelitian ini menggunakan metode regresi berganda yang hasilnya menunjukkan bahwa ROI dan EVA berpengaruh terhadap return saham. Santoso (2009) dalam penelitiannya menguji tentang pengaruh price earning ratio (PER), ROI, EPS, inventory turn over (ITO) dan current ratio (CR) terhadap harga saham pada industri lem yang terdaftar di BEI. Penelitian ini menggunakan sampel 4 perusahaan lem dengan periode data yang digunakan adalah 2003 - 2007. Hasil dari penelitian jika menggunakan uji $\mathrm{F}$ adalah PER, ROI, EPS, ITO dan CR berpengaruh terhadap harga saham sedangkan jika menggunakan uji t hanya ROI, EPS dan ITO yang berpengaruh terhadap harga saham.

Penelitian oleh Yuanita (2010) menjelaskan bahwa tidak ada pengaruh pengumuman deviden terhadap variabilitas keuntungan saham. Penelitian tersebut menguji pengaruh pengumuman deviden tunai ditinjau dari kenaikan dan penurunan dividen terhadap variabilitas tingkat keuntungan saham dalam sektor 
industri yang sama di BEI. Sampel yang digunakan adalah perusahaan yang telah tercatat di BEI yang mengumumkan deviden secara berturut-turut pada periode 2006 - 2008. Alimah (2011) dalam penelitiannya menunjukkan bahwa EPS, PER, ROI dan ROE tidak berpengaruh terhadap return saham baik secara simultan maupun parsial. Penelitian ini menggunakan populasi seluruh perusahaan retail di BEI periode 2005-2009 dengan jumlah sampel 16 perusahaan.

\section{Model Penelitian}

Model kerangka konseptual yang dikembangkan dalam penelitian ini adalah sebagai berikut:

Variabel Independen $\quad$ Variabel Dependen

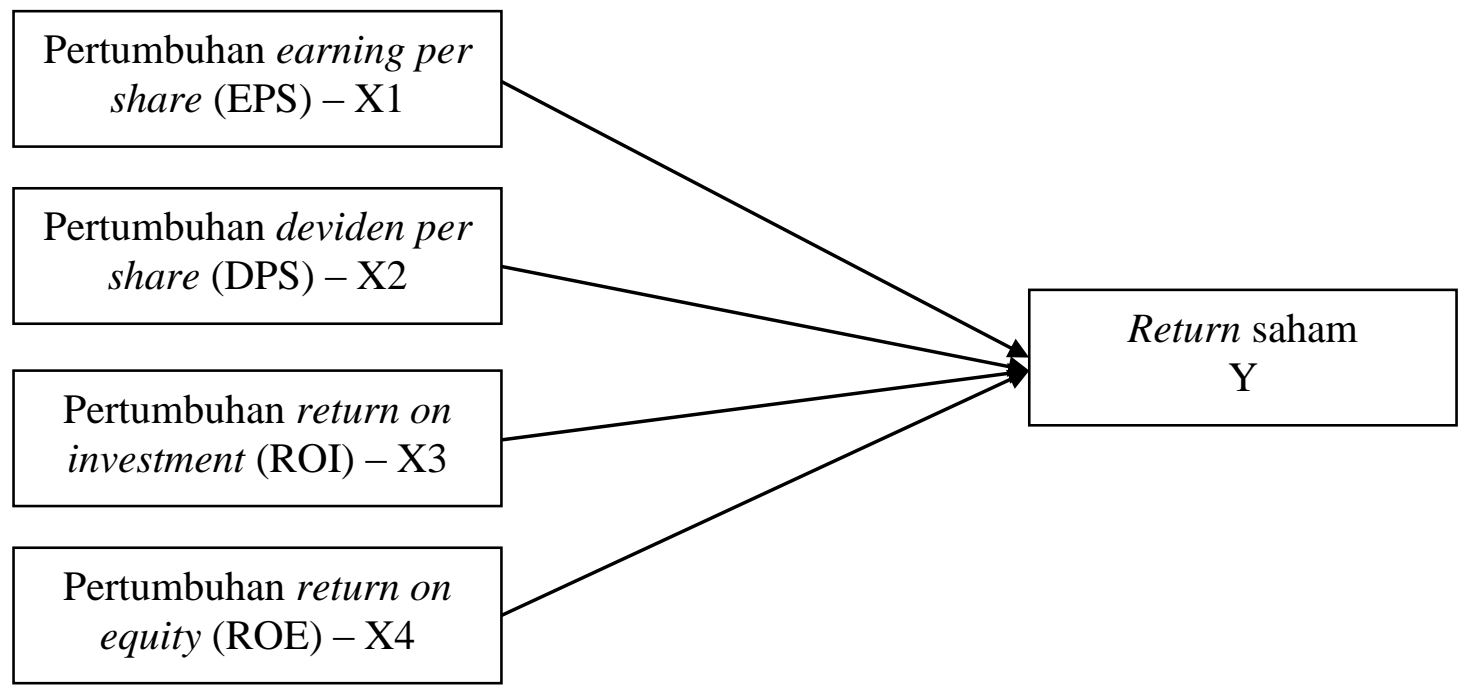

Gambar 1

Model Kerangka Konseptual

\section{METODA PENELITIAN}

\section{Populasi dan Sampel}

Populasi dalam penelitian ini adalah perusahaan yang terdaftar di Bursa Efek Indonesia sedangkan sampel yang digunakan yaitu perusahaan yang terdaftar di LQ-45 yang mengumumkan laba dan membayarkan deviden pada periode penelitian yaitu 2005-2010. Data yang digunakan dalam penelitian adalah data sekunder yang diambil dari Indonesia Capital Market Dictiory (ICMD) dan database pasar modal. 


\section{Definisi Operasional dan Pengukuran Variabel}

Variabel independen dalam penelitian ini adalah earning per share (EPS), deviden per share (DPS), return on investment (ROI), dan return on equity (ROE). EPS $\left(\mathrm{X}_{1}\right)$ akan mempengaruhi perilaku investor jika pertumbuhannya naik dan akan bereaksi pada perubahan harga saham dan pada akhirnya akan mempengaruhi return saham. EPS dapat diukur dengan menggunakan formula berikut:

Earning per Share $($ EPS) $=$
EAT (Iaba sebelum pajak)

Jumlah saham yang beredar

Setiap perusahaan membagikan deviden kepada pemegang saham akan memberikan respon yang positif dari para investor dimana akan mempengaruhi return saham. DPS $\left(\mathrm{X}_{2}\right)$ dapat diukur dengan rumus sebagai berikut:

$$
\text { Dividen per Share }(\text { DPS })=\quad \begin{aligned}
& \text { EAT (Iaba sebelum pajak) } \\
& \cline { 2 - 2 } \text { Jumlah saham yang beredar }
\end{aligned}
$$

Return on investment (ROI) digunakan untuk menunjukkan kemampuan perusahaan untuk dapat memperoleh laba yang tersedia bagi pemegang saham. ROI $\left(\mathrm{X}_{3}\right)$ dipengaruhi oleh besar kecilnya hutang perusahaan, apabila proporsi hutang makin besar maka ROI juga akan semakin besar (Sartono, 1997). Formula yang digunakan adalah sebagai berikut:

$$
\text { Return on Investment }(\mathrm{ROI})=\frac{\text { Iaba setelah pajak }}{\text { Total aktiva }}
$$

ROE atau sering disebut dengan rentabilitas modal sendiri dimaksudkan untuk mengukur seberapa banyak keuntungan yang menjadi hak pemilik modal sendiri (Martono dan Agus Harjito, 2008: 58). Rumus yang digunakan adalah sebagai berikut:

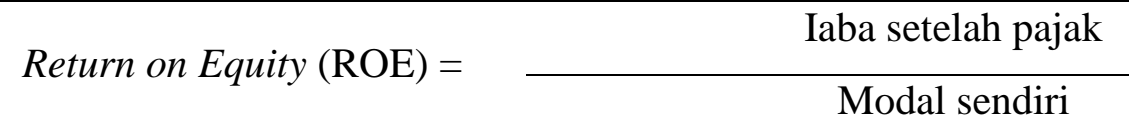


Sedangkan variabel dependen yang digunakan dalam penelitian adalah return saham. Adapun rumus yang digunakan adalah dengan menggunakan metode return saham relatif (Mulyanti, 2009). Return saham yang digunakan adalah lima hari sebelum publikasi, saat publikasi dan lima hari sesudah publikasi laporan keuangan.

Return Saham $=\quad \frac{\mathrm{P}_{\mathrm{t}}-\mathrm{P}_{\mathrm{t}-1}}{\mathrm{P}_{\mathrm{t}-1}}$

Keterangan:

$\mathrm{P}_{\mathrm{t}}=$ harga saham pada hari ke $\mathrm{t}$

$\mathrm{P}_{\mathrm{t}-1}=$ harga saham pada hari sebelumnya

\section{Alat Analisis Data}

\section{Regresi Linier Berganda}

\section{Uji Asumsi Klasik}

a. Uji normalitas bertujuan untuk menguji dalam model regresi, variabel penganggu atau residual memiliki distribusi normal. Cara yang digunakan untuk mendeteksi apakah residual berdistribusi normal atau tidak adalah dengan analisis grafik. Jika data distribusi normal, maka garis yang menggambarkan data sesungguhnya akan mengikuti garis diagonalnya, selain itu dapat digunakan uji statistik kolmogrov-smirnov (K-S) (Ghozali, 2006: 147-151). Sedangkan Ghozali (2011) menjelaskan apabila nilai signifikansi $<0,05$ maka data residual tidak berdistribusi normal dan sebaliknya apabila nilai signifikansi > 0,05 maka data residual berdistribusi normal.

b. Uji multikolinieritas bertujuan untuk menguji model regresi ditemukan korelasi antar variabel bebas (independen) (Ghozali, 2009). Uji multikolinieritas merupakan syarat regresi berganda yang dapat dilakukan dengan melihat matrik korelasi variabel independen dan melihat nilai tolerance dan variance inflation factor (VIF). Nilai yang umum dipakai untuk menunjukkan adanya multikolinieritas adalah nilai tolerance $\leq 10$ atau sama dengan nilai $\mathrm{VIF} \geq 10$.

c. Uji autokorelasi bertujuan untuk menguji dalam model regresi linier ada korelasi antara kesalahan pengganggu pada periode t-1 (sebelumnya). Deteksi autokorelasi dapat menggunakan Uji Durbin-Watson (DW test), pengambilan 
keputusan ada tidaknya autokorelasi yaitu apabila $\mathrm{Du}<\mathrm{d}<4$-du maka variabel terbebas dari autokorelasi.

d. Uji heteroskedastisitas bertujuan menguji dalam model regresi terjadi ketidaksamaan variance dari residual satu pengamatan ke pengamatan yang lain. Pengujian heteroskedastisitas dapat dilakukan dengan melihat grafik plot antara nilai prediksi variabel terikat (dependen) yaitu ZPRED dengan residualnya SRESID. Deteksi ada tidaknya heteroskedastisitas dapat dilakukan dengan melihat ada tidaknya pola tertentu pada grafik scaterrplot antara SRESID dan ZPRED (Ghozali, 2009).

\section{Pengujian Hipotesis}

\section{Koefisien Determinasi}

Koefisien determinasi (R-square) pada intinya mengukur seberapa jauh kemampuan model dalam menerangkan variasi variabel dependen. Nilai koefisien determinasi adalah antara nol dan satu. Nilai R-square yang kecil berarti kemampuan variabel - variabel independen dalam menjelaskan variabel dependen amat terbatas. Nilai yang mendekati satu berarti variabel independen memberikan hampir semua informasi yang dibutuhkan untuk memprediksi variabel dependen (Intan, 2009)

\section{Uji Statistik F}

Ghozali (2006: 88) uji statistik F pada dasarnya menunjukkan semua kemampuan variabel independen atau bebas yang dimasukkan dalam model mempunyai pengaruh secara bersama-sama terhadap variabel dependen atau terikat dengan rumus sebagai berikut (Kurniawati, 2006: 56):

$$
\mathrm{Y}=a+b 1 \times 1+b 1 \times 2+b 1 \times 3+b 1 \times 4+e
$$

Keterangan:

Y: $\quad$ Return Saham

a: $\quad$ Konstanta

b1: Koefisien Regresi

x1: Pertumbuhan EPS

x2: Pertumbuhan EPS 


\section{x3: $\quad$ Pertumbuhan EPS \\ x4: Pertumbuhan EPS \\ e: $\quad$ Error}

\section{Uji Statistik t}

Uji t bertujuan untuk mengetahui masing-masing variabel yaitu earning per share (EPS), deviden per share (DPS), return on investment (ROI) dan return on equity (ROE) secara individu berpengaruh terhadap return saham. Hipotesis alternatif (Ha) diterima apabila nilai signifikansi $<\alpha(5 \%)$ dan sebaliknya apabila nilai signifikansi $>\alpha(5 \%)$ maka hipotesis alternatif (Ha) tidak dapat diterima (tidak dapat menolak $\mathrm{H}_{0}$ ) (Kurniawati, 2006: 56).

\section{PEMBAHASAN}

\section{Hasil Uji Asumsi Klasik}

\section{Uji Normalitas}

Penelitian ini menggunakan uji normalitas Kolmogrov-Smirnov dimana hasilnya menunjukkan bahwa data residual berdistribusi normal. Hal ini dapat dilihat dari nilai signifikansi > 0,05 baik saat return $\mathrm{H}-5$ sampai dengan return $\mathrm{H}+5$.

Tabel 1

Hasil Uji Normalitas

\begin{tabular}{|c|c|}
\hline Keterangan & Asymp. Sig. (2 tailed) \\
\hline Return H+5 & 0,451 \\
\hline Return H+4 & 0,216 \\
\hline Return H+3 & 0,613 \\
\hline Return H+2 & 0,135 \\
\hline Return H+1 & 0,556 \\
\hline Return H & 0,595 \\
\hline Return H-1 & 0,999 \\
\hline Return H-2 & 0,884 \\
\hline Return H-3 & 0,327 \\
\hline Return H-4 & 0,759 \\
\hline Return H-5 & 0,326 \\
\hline
\end{tabular}

Sumber: Data sekunder, diolah (2012) 


\section{Uji Multikolinieritas}

Hasil pengujian multikolinieritas baik saat return H-5 sampai dengan return H+5 mempunyai nilai VIF yang sama, yaitu pertumbuhan EPS $(6,555)$, pertumbuhan DPS $(1,017)$, pertumbuhan ROI $(1,059)$ dan pertumbuhan ROE $(6,458)$ yang menunjukkan bahwa variabel bebas dari multikolinieritas, hal ini dapat dilihat dari semua nilai $\mathrm{VIF} \leq 10$.

Tabel 2

Hasil Uji Multikolinieritas

\begin{tabular}{|l|c|c|c|c|}
\hline \multirow{2}{*}{ Keterangan } & \multicolumn{4}{|c|}{ VIF } \\
\cline { 2 - 5 } & $\begin{array}{c}\text { Pertumbuhan } \\
\text { EPS }\end{array}$ & $\begin{array}{c}\text { Pertumbuhan } \\
\text { DPS }\end{array}$ & $\begin{array}{c}\text { Pertumbuhan } \\
\text { ROI }\end{array}$ & $\begin{array}{c}\text { Petumbuhan } \\
\text { ROE }\end{array}$ \\
\hline $\begin{array}{l}\text { Return H-5 s/d } \\
\text { return H+5 }\end{array}$ & 6,555 & 1,017 & 1,059 & 6,458 \\
\hline
\end{tabular}

Sumber: Data sekunder, diolah (2012)

\section{Uji Autokorelasi}

Pengujian autokorelasi dengan menggunakan Durbin-Watson (DW) menyimpulkan tidak terjadi autokorelasi. Hal ini disebabkan karena $\mathrm{k}=4, \alpha=5 \%$ dan $\mathrm{n}=75$, maka nilai du 1,739 dan dl 1,515. Hal ini dapat dilihat dari nilai $\mathrm{du}<\mathrm{d}<4$-du.

\section{Tabel 2}

Hasil Uji Autokorelasi

\begin{tabular}{|c|c|c|c|c|c|}
\hline Keterangan & $\mathrm{d}$ & $\mathrm{du}$ & $\mathrm{dl}$ & 4-du & $\mathrm{Du}<\mathrm{d}<(4-\mathrm{du})$ \\
\hline Return $\mathrm{H}+5$ & 1,952 & \multirow{11}{*}{1,739} & \multirow{11}{*}{1,515} & \multirow{11}{*}{2,261} & $1,739<1,952<2,261$ \\
\hline Return $\mathrm{H}+4$ & 1,911 & & & & $1,739<1,911<2,261$ \\
\hline Return $\mathrm{H}+3$ & 2,149 & & & & $1,739<2,149<2,261$ \\
\hline Return $\mathrm{H}+2$ & 1,815 & & & & $1,739<1,815<2,261$ \\
\hline Return $\mathrm{H}+1$ & 1,885 & & & & $1,739<1,885<2,261$ \\
\hline Return $\mathrm{H}$ & 1,958 & & & & $1,739<1,958<2,261$ \\
\hline Return H-1 & 2,185 & & & & $1,739<2,185<2,261$ \\
\hline Return H-2 & 1,893 & & & & $1,739<1,893<2,261$ \\
\hline Return H-3 & 1,909 & & & & $1,739<1,909<2,261$ \\
\hline Return H-4 & 2,050 & & & & $1,739<2,050<2,261$ \\
\hline Return H-5 & 1,868 & & & & $1,739<1,868<2,261$ \\
\hline
\end{tabular}

Sumber: Data sekunder, diolah (2012) 


\section{Uji Heterokedastisitas}

Hasil dari pengujian heteroskedastisitas dapat dilihat di grafik scatterplots yang menunjukkan bahwa tidak terjadi heteroskedastisitas baik saat return $\mathrm{H}-5$ sampai dengan $\mathrm{H}+5$.
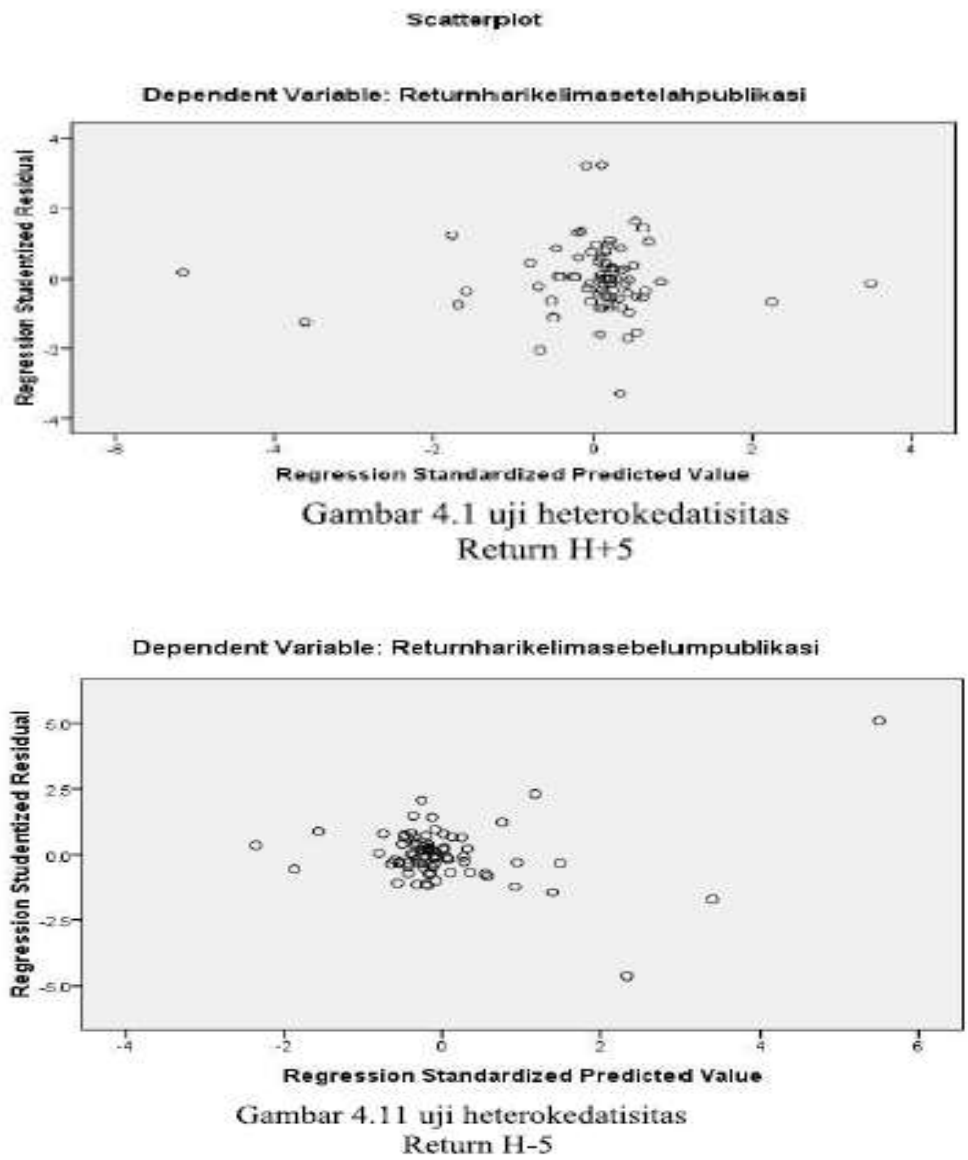

\section{Pengujian Hipotesis}

\section{Koefisien Determinasi}

Hasil perhitungan menunjukkan bahwa R-Square tertinggi pada saat return H-5 (0,153). Hal ini berarti bahwa pada saat return H-5 variabel independen memberikan informasi yang paling banyak untuk memprediksi variabel dependen, sedangkan pada saat return $H(0,011)$ memberikan informasi yang paling sedikit untuk memprediksi variabel dependen, hal ini disebabkan karena pada saat return $\mathrm{H}$ mempunyai R-square paling sedikit. Berdasarkan tabel juga dapat dilihat pada return $\mathrm{H}-5$ sampai dengan $\mathrm{H}+5$ menunjukkan hubungan antar variabel tidak kuat karena semua mempunyai nilai $\mathrm{R}<0,5$. 
Tabel 1

Hasil Uji $\mathbf{R}^{2}$

\begin{tabular}{|c|c|c|}
\hline Keterangan & $\boldsymbol{R}$ & $\boldsymbol{R}$-square \\
\hline Return H+5 & 0,114 & 0,013 \\
\hline Return H+4 & 0,326 & 0,107 \\
\hline Return H+3 & 0,319 & 0,102 \\
\hline Return H+2 & 0,163 & 0,027 \\
\hline Return H+1 & 0,237 & 0,056 \\
\hline Return H & 0,103 & 0,011 \\
\hline Return H-1 & 0,224 & 0,059 \\
\hline Return H-2 & 0,133 & 0,018 \\
\hline Return H-3 & 0,114 & 0,013 \\
\hline Return H-4 & 0,116 & 0,013 \\
\hline Return H-5 & 0,392 & 0,153 \\
\hline
\end{tabular}

Sumber: Data sekunder, diolah (2012)

\section{Uji Statistik F}

Berdasarkan hasil pengujian dapat dilihat bahwa variabel independen pada return H-5 berpengaruh secara bersama-sama pada variabel dependen karena pada saat return H-5 mempunyai nilai signifikansi < 5\%. Hal ini berarti bahwa pada H-5 terjadi kebocoran informasi.

Tabel 1

Hasil Uji F

\begin{tabular}{|c|c|}
\hline Keterangan & Signifikansi \\
\hline Return H+5 & 0,921 \\
\hline Return H+4 & 0,092 \\
\hline Return H+3 & 0,106 \\
\hline Return H+2 & 0,751 \\
\hline Return H+1 & 0,390 \\
\hline Return H & 0,944 \\
\hline Return H-1 & 0,361 \\
\hline Return H-2 & 0,867 \\
\hline Return H-3 & 0,921 \\
\hline Return H-4 & 0,916 \\
\hline Return H-5 & 0,019 \\
\hline
\end{tabular}

Sumber: Data sekunder, diolah (2012) 


\section{Uji Statistik $\mathbf{t}$}

Berdasarkan hasil pengujian statistik t, pertumbuhan EPS berpengaruh terhadap return saham yaitu pada $\mathrm{H}+3(0,007)$. Hal ini sesuai dengan penelitian yang dilakukan oleh Fitria (2006), Kurnia (2006) dan Santoso (2009).

Pertumbuhan DPS berpengaruh terhadap return saham yaitu return H-5 $(0,002)$ dan return $\mathrm{H}+4(0,032)$ karena pada saat tersebut mempunyai nilai signifikansi $<5 \%$. Hal ini sesuai dengan penelitian yang dilakukan oleh Widiastuti (2005) dan Kurnia (2006).

Pertumbuhan ROI berpengaruh terhadap return saham pada return $\mathrm{H}+1$ (0,045). Hasil tersebut mendukung penelitian yang dilakukan oleh Mulyanti (2009). Sedangkan ROE juga berpengaruh terhadap return saham pada return $\mathrm{H}+3(0,018)$.

\section{KESIMPULAN DAN SARAN}

Kesimpulan dalam penelitian ini adalah:

1. Pertumbuhan earning per share (EPS) memiliki pengaruh terhadap return saham pada perusahaan yang terdaftar di LQ-45 pada return $\mathrm{H}+3$.

2. Pertumbuhan deviden per share (DPS) memiliki pengaruh terhadap return saham pada perusahaan yang terdaftar di LQ-45 pada return $\mathrm{H}+4$ dan $\mathrm{H}-5$

3. Pertumbuhan return on investment (ROI) memiliki pengaruh terhadap return saham pada perusahaan yang terdaftar di LQ-45 pada return $\mathrm{H}+1$

4. Pertumbuhan return on equity (ROE) memiliki pengaruh terhadap return saham pada perusahaan yang terdaftar di LQ-45 pada return $\mathrm{H}+3$

Beberapa saran yang diajukan dari penelitian ini antara lain:

1. Peneliti selanjutnya agar membedakan antara pertumbuhan positif dan negatif, hal ini untuk mengetahui perbedaan reaksi pasar terhadap pertumbuhan positif maupun negatif.

2. Peneliti selanjutnya dapat membedakan rasio keuangan seperti net profit margin (NPM), return on asset (ROA) dan memperhatikan faktor lain seperti laju inflasi dan kebijakan manajemen. 


\section{DAFTAR PUSTAKA}

Alimah, Nur. 2011. Pengaruh Earning per Share (EPS), Price Earning Ratio (PER), Return on Investment (ROI), Return on Equity (ROE) terhadap Return Saham Perusahaan Retail. Skripsi. Yogyakarta. Universitas Ahmad Dahlan.

Artiani, Sri Fajar. 2008. Pengaruh Rasio Keuangan terhadap Pertumbuhan laba pada Perusahaan Besar Manufaktur dan Perusahaan Kecil Manufaktur yang Terdaftar di Bursa Efek Jakarta. Skripsi. Yogyakarta. Universitas Ahmad Dahlan.

Baridwan, Zaki. 1999. Intermediate Accounting. Yogyakarta.: BFFE UGM.

Budiarjo,Djoni, dan Joshe Hana Hapsari. 2011. "Pertumbuhan Earning per Share (EPS), Dividen per Share (DPS), dan Price Earning Ratio sebagai Dasar Keputusan Stock Split”. Jurnal Manajemen dan Kewirausahaan (Maret), hal. 91-98.

Fitria, Yessi. 2006. Pengaruh Earning per Share (EPS), Dividen per Share (DPS), terhadap Harga Saham pada Perusahaan Manufaktur yang Terdaftar di Bursa Efek Jakarta. Skripsi. Yogyakarta. Universitas Ahmad Dahlan.

Ghozali, Imam. 2006. Aplikasi Analisis Multivariate dengan SPSS. Semarang. Universitas Diponegoro.

, 2011. Aplikasi Analisis Multivariate dengan Program IBM SPSS 19. Semarang. Universitas Diponegoro.

Haryanto, Jogiyanto. 2005. Pasar Efisien Secara Keputusan. Jakarta: PT Gramedia Pustaka.

2009. Teori Portofolio dan Analisis Investasi. Yogyakarta. BFFE UGM.

Husnan, Suad. 1998. Manajemen Keuangan Teori dan Penerapan (Keputusan Jangka Pendek). Yogyakarta. BFFE UGM.

Indrianto, Nur dan bambang Supomo. 2009. Metodologi Penelitian Bisnis. Yogyakarta: BFFE UGM. 
Intan, Taranika. 2009. Pengaruh Earning per Share dan Dividen per Share terhadap Harga Saham pada Perusahaan go public di Bursa efek Indonesia. Skripsi. Medan: Universitas Sumatra utara.

Kendarto, Andita. 2009. Pengaruh Earning per Share (EPS), Return on Equity (ROE), dan Debt to Equity Ratio (DER) terhadap Harga Saham pada Perusahaan Retail yang Terdaftar di Bursa Efek Jakarta. Skripsi. Yogyakarta: Universitas Ahmad Dahlan.

Kurnia, 2008. Pengaruh Earning per Share (EPS), Return on Equity (ROE), dan Debt to Equity Ratio (DER) terhadap Harga Saham pada Perusahaan Manufaktur yang Terdaftar di Bursa Efek Jakarta. Skripsi. Yogyakarta: Universitas Ahmad Dahlan.

Kurniawati, Indah. 2006. Modul Pengelolaan Data Elektronik. Yogyakarta: Universitas Ahmad Dahlan.

Martono dan Agus Harjito. 2008. Manajemen Keuangan. Yogyakarta: Ekonosia.

Mulyati, Santri. 2009. Analisis Pengaruh Return on Investment (ROI) dan Economic Value Added (EVA) terhadap Return Saham pada Perusahaan Manufaktur yang Terdaftar di Bursa efek Jakarta. Skripsi. Yogyakarta: Universitas Ahmad Dahlan.

Muslimah. 2008. Analisis Pengaruh Earning per Share (EPS), Debt to Equity Ratio (DER), Return on Equity (ROE), dan Return on Investment (ROI) terhadap Harga Saham pada PT Aneka Tambang Tbk. Skripsi. Yogyakarta: Universitas Ahmad Dahlan.

Natsir, Muh. 2007. "Pengaruh Earning per Share (EPS), Debt to Equity Ratio (DER), dan Stock Split terhadap Harga Saham". Jurnal Ekonomi dan Bisnis Indonesia (Agustus), hal. 175-180.

Nazwirman. 2008. "Penilaian Harga Saham dengan Price Earning Ratio (PER): Studi Kasus pada Saham Industri Makanan dan Minuman di Bursa Efek Indonesia". Makara Sosial Humaniora (Desember), hal 90-106.

Napaj, Awat. 1999. Manajemen Keuangan Pendekatan Matematis. Jakarta: PT Gramedia Utama.

Prastowo , Dwi dan Rifka Juliaty. 2008. Analisis Laporan Keuangan Konsep dan Aplikasi. Yogyakarta: YKP. 
Santoso, Eko Dwi. 2009. Analisis Pengaruh Price Earning Ratio (PER), Return on Investment (ROI), Earning per Share (EPS), Inventory Turn Over (ITO), dan Current Ratio (CR) terhadap Harga Saham pada Industri lem (adhesive) yang Terdaftar di Bursa efek Indonesia. Skripsi. Yogyakarta: Universitas Ahmad Dahlan.

Sartono, Agus. 1997. Ringkasan Teori Manajemen Keuangan Soal dan Penyelesaian. Yogyakarta: BPFE UGM.

Subiyantoro, Edi dan Fransisca Andreani. 2003. "Analisis Faktor-faktor yang Mempengaruhi Harga Saham". Jurnal Manajemen dan Kewirausahaan (September), hal. 171-180.

Susilo, Bambang. 2009. Pasar Modal Mekanisme perdagangan Saham, Analisis Saham, dan Strategi di Bursa Efek Indonesia. Yogyakarta: UPP STIM YKPN.

Widiyastuti, Tri. 2005. Pengaruh Earning per Share (EPS), Return on Equity (ROE), dan Return on Investment (ROI) terhadap Harga Saham Perusahaan Telekomunikasi yang Terdaftar di Bursa Jakarta. Skripsi. Yogyakarta: Universitas Ahmad Dahlan.

Yanita, Vian. 2010. Pengaruh Pengumuman Dividen Tunai Ditinjau dari Kenaikan dan Penurunan Dividen terhadap Variabilitas Tingkat Keuntungan Saham dalam Sektor Industri yang Sama di Bursa Efek Indonesia. Skripsi. Yogyakarta: Universitas Ahmad Dahlan. 